\title{
New species of Palmorchis Barb. Rodr. (Orchidaceae) from Colombia
}

\author{
Dariusz L. Szlachetko \& Przemysław Baranow
}

\begin{abstract}
SZLACHETKO, D. L. \& P. BARANOW (2013). New species of Palmorchis Barb. Rodr. (Orchidaceae) from Colombia. Candollea 68: 105-113. In English, English and French abstract.

Five new species of Palmorchis Barb. Rodr. (Orchidaceae, Vanilloideae) from Colombia, Palmorchis carlos-parrae Szlach. \& Baranow, Palmorchis fractiflexa Szlach. \& Baranow, Palmorchis maculata Szlach. \& Baranow, Palmorchis misas-urretae Szlach. \& Baranow and Palmorchis valdiviesoana Szlach. \& Baranow, are described and illustrated. Diagnostic characters of the new taxa are compared with the closely related species in Colombia and an identification key is proposed. Ecology, habitat and distribution data for these taxa are also given.
\end{abstract}

\section{Key-words}

ORCHIDACEAE - Palmorchis - Colombia - Taxonomy

\section{Résumé}

SZLACHETKO, D. L. \& P. BARANOW (2013). Nouvelles espèces de Palmorchis Barb. Rodr. (Orchidaceae) de Colombie. Candollea 68: 105-113. En anglais, résumés français et anglais.

Cinq nouvelles espèces de Palmorchis Barb. Rodr. (Orchidaceae, Vanilloideae) de Colombie, Palmorchis carlos-parrae Szlach. \& Baranow, Palmorchis fractiflexa Szlach. \& Baranow, Palmorchis maculata Szlach. \& Baranow, Palmorchis misas-urretae Szlach. \& Baranow and Palmorchis valdiviesoana Szlach. \& Baranow, sont décrites et illustrées. Les caractères diagnostiques de ces taxons nouveaux sont donnés et comparés avec les espèces apparentées, et une clé d'identification est donnée. L'écologie, l'habitat et la distribution de ces taxons sont aussi fournis. 
Palmorchis Barb. Rodr. (Orchidaceae, Vanilloideae) is a small genus with less than 20 species distributed in tropical areas of Central and South America. It is represented by terrestrial plants of various sizes, with diminutive storage organs and with thin roots. Stems are elongate, somewhat woody, reed-like, branching, leafy. Leaves are large, oblong to elliptic-lanceolate, acute to acuminate, thin, plicate, strongly veined. Inflorescence is terminal or lateral, with inconspicuous flowers opening in succession. Flowers are tubular, spreading at the apex, whitish or greenish, often with a red, large spot at the lip apex. Tepals are subsimilar or similar, narrowly lanceolate or oblanceolate. Lip is oblong, widened at the apex, and here more or less 3-lobed, covered by hairs or various thickenings on the inner surface, tubular at the base. Gynostemium is elongate, rather slender, erect, often more or less curved at the apex. There are 4, oblong-ovoid to oblong-clavate, slightly falcate, relatively compact pollinia.

Palmorchis is one of the least known orchid genera in the New World (HÁgsater \& al., 1996). All plants in a population were observed flowering in the same day, and the delicate flowers last for only a few hours. When not in flower, the plants look much like forest floor grasses or plantlets of palms (Dressler, 1993a; Dressler, 1993b).

The short time of flowering and the inconspicuous appearance of sterile plants can be the reasons for the small number of herbarium collections representing the genus. However, the detailed study of the materials collected in COL resulted in the discovery of some taxa distinct from all previously described species of Palmorchis. In the present paper, five new species of the genus are described and illustrated.

Key to Colombian species of Palmorchis (including P. pandurata C. Schweinf. \& Correll and P. guianensis (Schltr.) C. Schweinf. \& Correll which are suspected to occur in the country)

1. Lip widest near the middle 2

1a. Lip widest at or near the apex 4

2. Hypochile narrowly triangular, widest just below the apex, with two lamellae running in the apical third, lateral lobes falcate, acute.... 1. P. carlos-parrae Szlach. \& Baranow

2a. Hypochile not as above ... 3

3. Lip $6 \mathrm{~mm}$ long im total, ciliate at the base only 2. P. fractiflexa Szlach. \& Baranow

3a. Lip 17-34 mm long in total, pubescent on the inner surface. 4. P. misas-urretae Szlach. \& Baranow

4. Lip sinuate or notched at the apex.... 5

4a. Lip middle lobe obscure, ligulate to lanceolate.
5. Leaves to $9.5 \mathrm{~cm}$ wide, lip pandurate in outline, pubescent at base ......... P. pandurata C. Schweinf. \& Correll

5a. Width of the leaves here lacking Lip flabellate-rotundate in outline, pubescent or pilose on the inner surface ..... 6

6. Leaves $38-42 \mathrm{~cm}$ long, $10-11 \mathrm{~cm}$ wide...

P. deceptorius Veyret \& Szlach.

6a. Leaves to $28 \mathrm{~cm}$ long, $3-5 \mathrm{~cm}$ wide. P. powellii (Ames) C. Schweinf. \& Correll

7. Lip middle lobe truncate .. 8

7a. Lip middle lobe acute to subobtuse .............................. 10

8. Leaves narrowly lanceolate to linear-lanceolate, long acuminate, lip pubescent in the lower half.

P. puber (Cogn.) Garay

8a. Leaves elliptic to ovate-elliptic, acuminate, lip glabrous in the lower part 9

9. Leaves blades up to $24 \mathrm{~cm}$ long and $9 \mathrm{~cm}$ wide, elliptic to ovate-elliptic, acuminate, petiole up to $10 \mathrm{~cm}$ long, floral segments 10-13 mm long and 1.6-6 mm wide

P. lobulata (Mansf.) C. Schweinf. \& Correll

9a. Leaves blades $13-15 \mathrm{~cm}$ long and 3.5-4 cm wide, oblongelliptic, petiole up to $5 \mathrm{~cm}$ long, floral segments 6.2 $7.2 \mathrm{~mm}$ long and 2.2-3.5 $\mathrm{mm}$ wide.

P. guianensis (Schltr.) C. Schweinf. \& Correll

10. Lip and tepals over $9 \mathrm{~mm}$ long 11

10a. Lip up to $6.5 \mathrm{~mm}$ long, tepals to $8 \mathrm{~mm}$ long .............. 12

11. Lip with basal, woolly pubescent keel and two rather thick lamellae running along almost entire lip length

5. P. valdiviesoanus Szlach. \& Baranow

11a. Lip not as above 13

12. Hypochile lower half oblong, pubescent and distinctly thickened along midvein, apical half almost rounded to transversely elliptic, with thick, glabrous 3-lobed callus at the apex; epichile clawed, subcordate, acuminate, thickened in the centre .... 3. P. maculata Szlach. \& Baranow

12a. Hypochile with a linear, conduplicate, puberulent base, lamina trapezoid in outline, lateral lobes obtuse; epichile sessile, fleshy, oblong-lanceolate, subacute

P. colombiana Garay

13. Gynostemium glabrous..... P. trilobulata L. O. Williams

13a. Gynostemium pubescent on the ventral surface.

P. trinotata Dressler 
1. Palmorchis carlos-parrae Szlach. \& Baranow, spec. nova (Fig. 1).

Typus: Colombia. Amazonas: Rio Caqueta. Frente a la isla del Tigre, zona aluvial., $200 \mathrm{~m}$, 26.IX.1988, G. Galeano \& A. Mirana 1939 (holo-: COL [380214]!).

Differs from other species of the genus by the larger flowers, thin floral segments, distinctly three-lobed lip, the lip lateral lobes falcate, acute, and the lip middle lobe acute.

Plants terrestrial, up to $80 \mathrm{~cm}$ tall, maybe more, leafy. Leaves petiolate; sheath and petiole to $20(-25) \mathrm{cm}$ long, narrow, canaliculate; blade to $60(-62) \mathrm{cm}$ long and $13 \mathrm{~cm}$ wide, oblong-elliptic to elliptic-lanceolate, acute to acuminate. Inflorescence a panicle, $7(-15) \mathrm{cm}$ long or more, branching, densely many-flowered, apical; rachis furfuraceous. Flowers large for the genus, opening successively, flower segments thin. Floral bracts to 30(-40) $\mathrm{mm}$ long, lanceolate, pubescent on both surfaces. Pedicel and ovary $18 \mathrm{~mm}$ long, glabrous. Dorsal sepal $32 \mathrm{~mm}$ long, $3 \mathrm{~mm}$ wide, oblong-lanceolate to linear-lanceolate, acute to acuminate, concave near the centre, 5-nerved. Petals $28 \mathrm{~mm}$ long, $2 \mathrm{~mm}$ wide, oblong-linear, sigmoid, rounded at apex, 3-nerved, lateral nerves branching apically. Lateral sepals $32 \mathrm{~mm}$ long, $3 \mathrm{~mm}$ wide, linear-lanceolate to oblong-linear, sigmoid, long-acuminate, 5-nerved. Lip $26 \mathrm{~mm}$

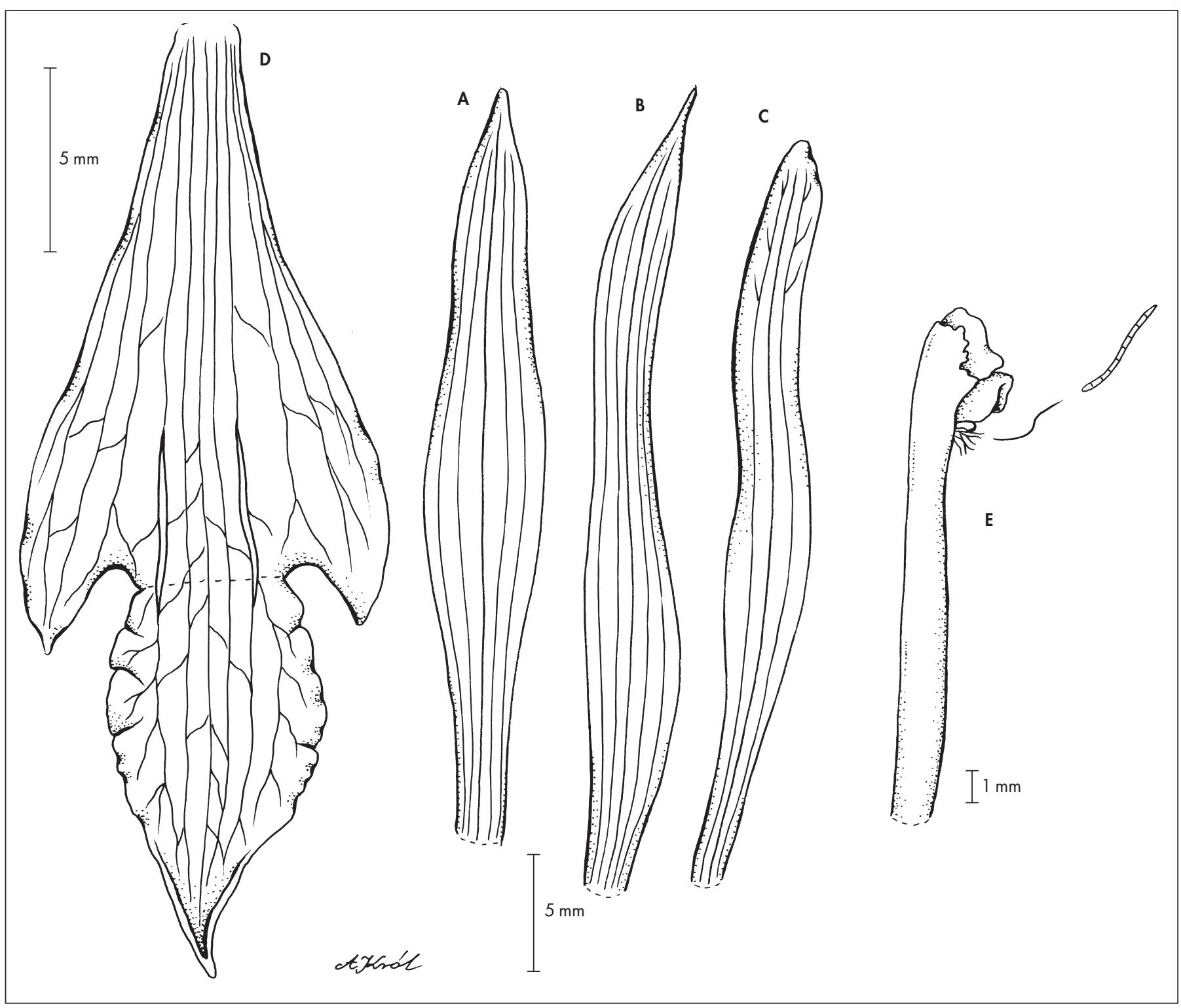

Fig. 1. - Palmorchis carlos-parrae Szlach. \& Baranow. A. Dorsal sepal ; B. Lateral sepal ; C. Petal ; D. Lip; E. Gynostemium.

[Galeano \& Mirana 1939, COL] [Drawn by A. Król] 
long in total, distinctly 3-lobed near the apical third, glabrous; epichile $19 \mathrm{~mm}$ long, $11 \mathrm{~mm}$ wide, narrowly triangular, broadest just below apex, with two lamellae running in the apical third, lateral lobes falcate, acute; hypochile $9 \mathrm{~mm}$ long, $4 \mathrm{~mm}$ wide, oblong-ovate to elliptic, long-acuminate, margins somewhat undulate. Gynostemium $16 \mathrm{~mm}$ long, erect, slender, with a tuft of segmented hairs just below stigma only.

Etymology. - Dedicated to Dr Carlos Parra, the curator of COL.

Ecology. - Terrestrial on lateritic soil, in wet areas.

Distribution. - Known from the Colombian departments of Amazonas and Chocó.

Representative specimens - Colombia. Chocó: Mpio. de Nuqui. Quebrada Chaqui. 77¹6’W 540’N, 200 m, II-III.1994, G. Galeano \& al. 4649 (COL!); Trail from Río Mecana to Alto de Mecana. Lateritic soil, mostly on ridge top, $6^{\circ} 15^{\prime} \mathrm{N} 77^{\circ} 25^{\prime} \mathrm{W}, 100-500 \mathrm{~m}$, 6.III.1983, A. Gentry \& A. Juncosa 41006 (COL!).

Notes. - Palmorchis carlos-parrae is unique in the genus, not similar to any other species known to us. It is characterized by the large habit and leaves. Its flowers are also relatively large as for the genus, with segments exceeding $30 \mathrm{~mm}$ in length. The lip is prominently 3-lobed, with the lateral lobes of the hypochile acute, falcate and the apex of midlobe longacuminate. The surface of the lip is glabrous with two short lamellae near the lip centre.

\section{Palmorchis fractiflexa Szlach. \& Baranow, spec. nova} (Fig. 2).

Typus: Colombia. Choco: Mpio. de Unguia. Entre Balboa, Jilgal y Titumate, potreros y relictos de bosque de colina, $8^{\circ} 19^{\prime} \mathrm{N} 77^{\circ} 05^{\prime} \mathrm{W}, 20-80 \mathrm{~m}, 22 . \mathrm{XI} .2001$, R. Bernal, G. Galeano, E. Ballesteros \& R. Morales 3094 (holo-: COL [505180]!).

Differs from all other species of the genus by the fractiflex rachis. In floral structure it is similar to P. pandurata, but the epichile of P. fractiflexa is transversely elliptic, obtuse and the lip callus consists of 3 lamellae running from lip base to the apex, higher in the upper part.

Plants 20(-30) cm tall, leafy. Leaves 3-5, gathered in the upper part of the stem, petiolate; petiole and sheath to $3(-6) \mathrm{cm}$ long; blade to $12(-20) \mathrm{cm}$ long, $3.5(-6) \mathrm{cm}$ wide, lanceolate to oblong-lanceolate, acuminate. Inflorescence a raceme, to $3(-7) \mathrm{cm}$ long, apical, supported basally by 2.5 $(-8) \mathrm{cm}$ long, linear, acute spatha; rachis $1.5-2 \mathrm{~cm}$ long, somewhat fractiflex, glabrous, flowers distichously arranged. Flowers small, glabrous. Floral bracts to $6 \mathrm{~mm}$ long, ovate-lanceolate, acute, glabrous. Pedicel and ovary to $4 \mathrm{~mm}$ long, glabrous. Dorsal sepal $7 \mathrm{~mm}$ long, $1.2 \mathrm{~mm}$ wide, oblongoblanceolate to linear-oblanceolate, acute, with main nerve somewhat thickened on outside, 5-nerved. Petals $6.5 \mathrm{~mm}$ long,

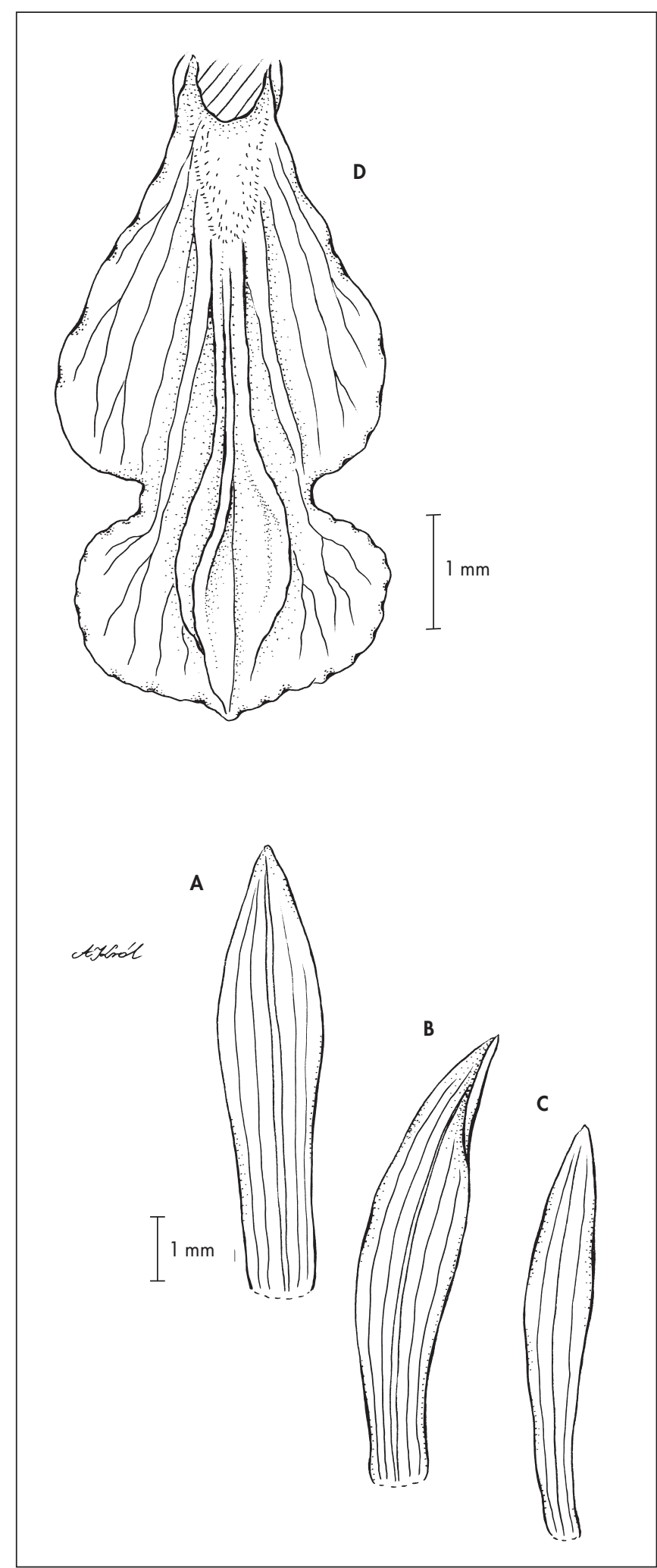

Fig. 2. - Palmorchis fractiflexa Szlach. \& Baranow. A. Dorsal sepal; B. Lateral sepal; C. Petal; D. Lip.

[Bernal \& al. 3094, COL] [Drawn by A. Król] 
$1 \mathrm{~mm}$ wide, linear-oblanceolate, subfalcate, subacute to subobtuse, 3-nerved. Lateral sepals $7 \mathrm{~mm}$ long, $1.2 \mathrm{~mm}$ wide, linearlanceolate, subacute, subfalcate, 5-nerved, with the main nerve thickened outside. Lip $6 \mathrm{~mm}$ long, subsessile, basally thickened, thickening ciliate, with 3 lamellae running from the base to the apex, much higher in apical half; hypochile $4 \mathrm{~mm}$ long, $2.5 \mathrm{~mm}$ wide, obtrullate to obovate, with two thickened lateral nerves on both sides of lamellae; epichile $2 \mathrm{~mm}$ long, $2.5 \mathrm{~mm}$ wide, transversely elliptic in outline, obtuse, margins somewhat erose. Gynostemium $5 \mathrm{~mm}$ long, ciliate in the lower part.

Etymology. - An allusion to the form of the rachis.

Ecology. - Terrestrial in forest.

Distribution. - Known from Colombian Chocó only.

Notes. - This species is unique in the genus Palmorchis by its fractiflex rachis. It is somewhat similar to P. pandurata, but its epichile is entire, transversely elliptic, obtuse and lip callus consists of 3 lamellae running from lip base to the apex, being highest in the upper part.

3. Palmorchis maculata Szlach. \& Baranow, spec. nova (Fig. 3).

Typus: Colombia. Amazonas: La Pedrera Mpio, Inspección de Santa Isabel, Parque Nacional Natural Cahuinari, Estación Biológica Puerto Barbados, Varzea (rebalse baja), rodeando una laguna pequeña, dominado por Myristicaceae, periantio blanco, $1^{\circ} 28^{\prime} \mathrm{S} 70^{\circ} 46^{\prime} \mathrm{W}, 200$ m., 1.XII. 1990, J. Pipoly, B. Rudas \& M. Letuama 12909 (holo-: COL [414885]!).

Similar to P. lobulata, but differs in the distinctly larger flowers, subcordate, acute epichile, large, three-lobed callus, and basal part of hypochile covered with hairs. Differs from P. pabstii by the three-lobed callus on the lip.

Plants relatively small for the genus, $14-16 \mathrm{~cm}$ tall. Leaves $3-4$, at the apex of the stem, petiolate; petiole and sheath 4$5 \mathrm{~cm}$ long; blade $12 \mathrm{~cm}$ long, $3 \mathrm{~cm}$ wide, oblong-lanceolate, acute to acuminate, densely and lightly spotted on the abaxial surface. Inflorescence a raceme $3.5 \mathrm{~cm}$ long, apical; rachis $1.8 \mathrm{~cm}$ long, subdensely 8-10-flowered. Flowers rather small, white. Floral bracts $5 \mathrm{~mm}$ long, ovate-lanceolate, furfuraceous on both surfaces. Pedicel and ovary $6 \mathrm{~mm}$ long, glabrous. Dorsal sepal 9-10 mm long, $2.2 \mathrm{~mm}$ wide, oblong-oblanceolate, subacute, 5-nerved, the main nerve thickened outside. Petals 9-10 mm long, $2.3 \mathrm{~mm}$ wide, oblong-oblanceolate, subfalcate, subacute, 5-nerved, nerves branching at the apex. Lateral sepals 9-10 $\mathrm{mm}$ long, $2.3 \mathrm{~mm}$ wide, oblong-oblanceolate, subfalcate, subacute, 5 -nerved, the main nerve thickened on outer surface. Lip 10-11 mm long, apically 3-lobed; hypochile 9$10 \mathrm{~mm}$ long, $5.5 \mathrm{~mm}$ wide, the lower half oblong, pubescent and distinctly thickened along midvein, apical half almost rounded to transversely elliptic, with a thick, glabrous, 3-lobed callus at the apex; epichile $1 \mathrm{~mm}$ long, $0.8 \mathrm{~mm}$ wide, clawed, subcordate, acuminate, thickened in the centre. Gynostemium $11 \mathrm{~mm}$ long, slender, pubescent on the lower surface below stigma.

Etymology. - An allusion to the leaves of this species spotted on the underside.

Ecology. - Terrestrial in forest.

Distribution. - Known from Colombian Amazonas only.

Representative specimens. - Colombia. Amazonas: La Pedrera Mpio, inspección de Santa Isabel. Parque pequena, dominado por Myristicaceae, perianto blanco, 1²8'S 7046'W, 200 m, 1.XII.1990, J. Pipoly, B. Rudas, \& M. Letuama 12909 (COL!, MO).

Notes. - The diagnostic feature of P. maculata is the prominent, 3-lobed lip callus, which distinguishes it clearly from both P. lobulata and P. pabstii Veyret. Additionally, the new species differs from the former by the larger flowers, with subcordate, acute epichile and pubescent basal half of hypochile. P. maculata is the only species of the genus known to us with spotted leaves.

\section{Palmorchis misas-urretae Szlach. \& Baranow, spec. nova} (Fig. 4).

Typus: Colombia. Chocó: N de la Costa Pacifica, s.loc., VII.1988, G. Misas Urreta 5 (holo-: COL [520156]!).

Similar in habit to P. carlos-parrae, but differs in the pubescent upper surface of the lip, the obtrullate hypochile, and the subquadrate, truncate epichile.

Leaves large, petiolate; blade $19 \mathrm{~cm}$ long, $3.5 \mathrm{~cm}$ wide, lanceolate to oblong-lanceolate, acuminate. Inflorescence a panicle $12 \mathrm{~cm}$ long, probably much longer, with 1 basal branch, many-flowered, apical. Flowers large for the genus, openning in succession, sepals furfuraceous, petals woolly pubescent on the outer surface, sparsely pubescent on the inner surface. Floral bracts $30 \mathrm{~mm}$ long, linear-lanceolate, acute, stiff, furfuraceous. Pedicel and ovary $23 \mathrm{~mm}$ long, furfuraceous. Dorsal sepal $32 \mathrm{~mm}$ long, $3.5 \mathrm{~mm}$ wide, linear-oblanceolate, acute, 7-nerved. Petals $33 \mathrm{~mm}$ long, $3 \mathrm{~mm}$ wide, linear in the lower two-thirds, obliquely ovate-lanceolate above, somewhat undulate, subobtuse, nerves 5, apically branching. Lateral sepals $33 \mathrm{~mm}$ long, $3 \mathrm{~mm}$ wide, linear-oblanceolate, falcate, subacute, 5-nerved. Lip $34 \mathrm{~mm}$ long in total, pubescent on the inner surface, with a keel running from the base to the apex, 3-lobed; hypochile $26 \mathrm{~mm}$ long, $12 \mathrm{~mm}$ wide, obtrullate above a linear claw, densely pubescent near the base and along keel; epichile $8 \mathrm{~mm}$ long, $6 \mathrm{~mm}$ wide, subquadrate, truncate at the apex, undulate along margins. Gynostemium $19 \mathrm{~mm}$ long, wholly glabrous. 


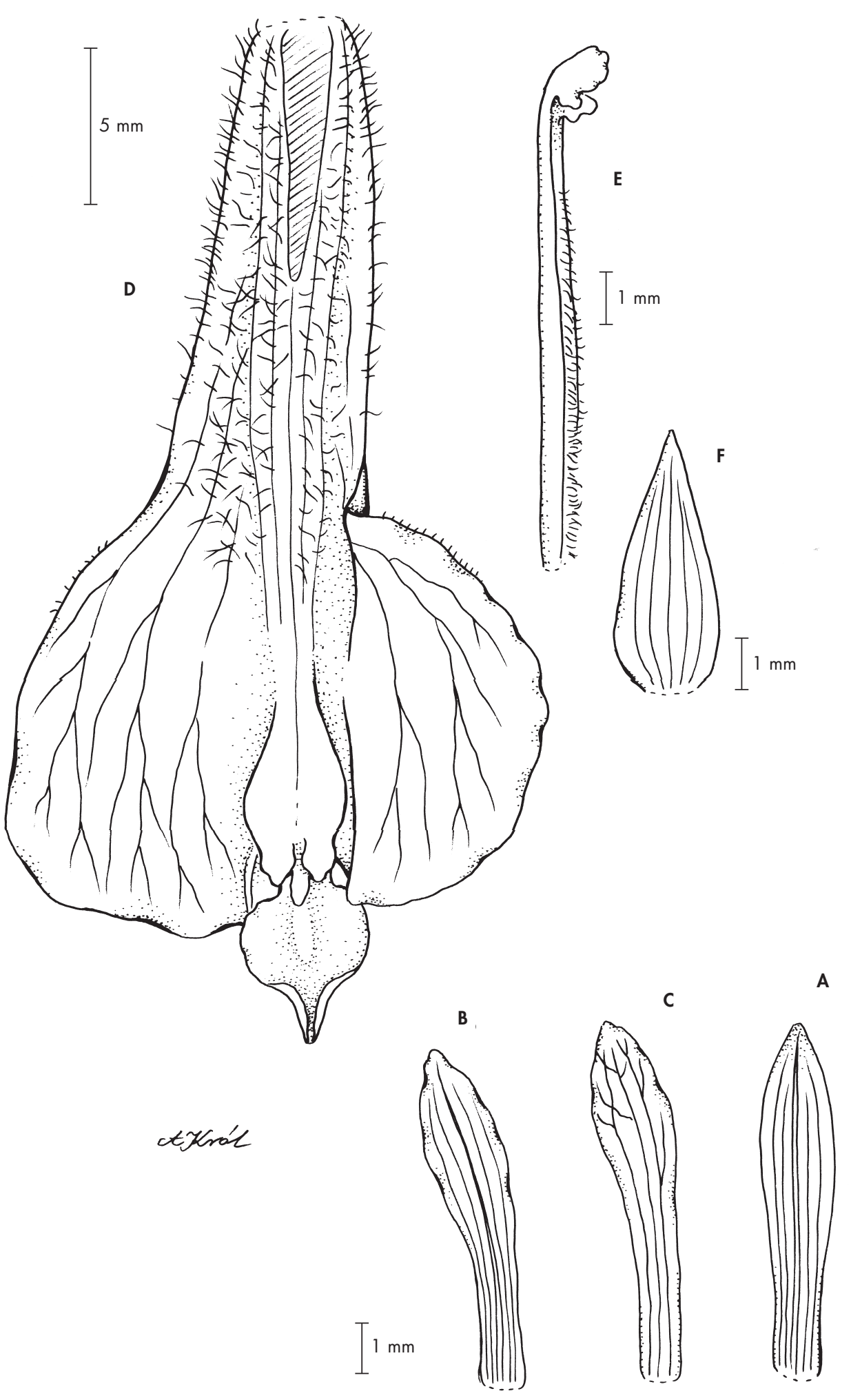

Fig. 3. - Palmorchis maculata Szlach. \& Baranow. A. Dorsal sepal ; B. Lateral sepal ; C. Petal ; D. Lip; E. Gynostemium ; F. Floral bract [Pipoly \& al. 12909, COL] [Drawn by A. Król] 


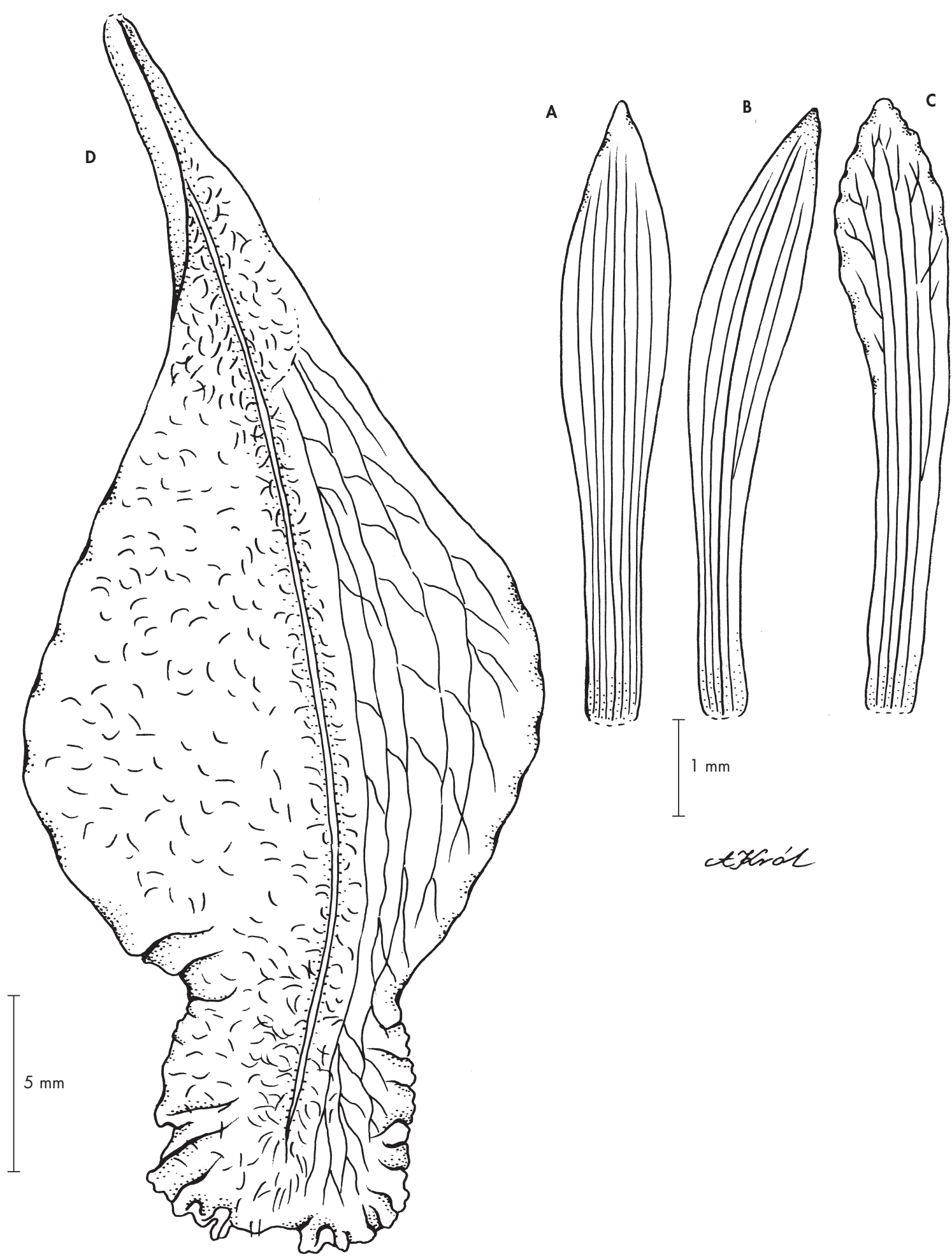

Fig. 4. - Palmorchis misas-urretae Szlach. \& Baranow: A. Dorsal sepal ; B. Lateral sepal ; C. Petal ; D. Lip. [Misas Urreta 5, COL] [Drawn by A. Król] 
Etymology. - Dedicated to Guillermo Misas Urreta, the author of Orquideas de la Serrania del Baudio, Chocó, Colombia who was the first to suggest that this plant could be a species new to science, and moreover is the collector of the type specimen.

Ecology. - Terrestrial.

Distribution. - Known only from the type collection.

Notes. - Only the apical part of plant remains in the type material. This species is similar to P. carlos-parrae in its habit, but the lip is pubescent on the upper surface, with keeled main nerve. The keel ranges from the base to the apex of the lip. The hypochile is obtrullate in general outline, the epichile is subquadrate, with truncate apex and undulate margins. This species could be related to P. pubescens Barb. Rodr. and P. prospectorum Veyret.

\section{Palmorchis valdiviesoana Szlach. \& Baranow, spec. nova} (Fig. 5).

Typus: Colombia. Vaupes: En Monfort, 29.XI.1952, Romero Castañeda 3843 (holo-: COL [64891]!).

Similar to P. guianensis, but differs in the obtriangular hypochile with basal, oblong, pubescent callus and two prominent lamellae running to the base of epichile which is ligulate-lanceolate and acute.

Plants at least $30 \mathrm{~cm}$ tall. Leaves petiolate; petiole and sheath $7 \mathrm{~cm}$ long; blade $24 \mathrm{~cm}$ long, $7 \mathrm{~cm}$ wide, oblong-elliptic, acuminate, delicate, with 7 prominent nerves. Inflorescence a raceme to $10 \mathrm{~cm}$ long, apical; rachis $4-5 \mathrm{~cm}$ long, pubescent, densely many-flowered. Flowers white, gynostemium red. Floral bracts $11 \mathrm{~mm}$ long, ovate-laceolate, acute, pubescent on both surfaces. Pedicel and ovary $8 \mathrm{~mm}$ long. Dorsal sepal $12 \mathrm{~mm}$ long, $2 \mathrm{~mm}$ wide, oblong-oblanceolate, acute, 5-nerved. Petals 11-12 mm long, $1.8 \mathrm{~mm}$ wide, oblong-lanceolate with a linear basal half, subfalcate, acuminate, 3-nerved, lateral nerves branching. Lateral sepals $13 \mathrm{~mm}$ long, $2 \mathrm{~mm}$ wide, oblong with lanceolate, acute apex, subfalcate, 5-nerved. Lip 13-14 mm long; hypochile 10-11 mm long, $6 \mathrm{~mm}$ wide, obtriangular, with a basal, woolly pubescent keel and two rather thick lamellae running along almost the entire lip length; epichile $3 \mathrm{~mm}$ long, $1 \mathrm{~mm}$ wide, ligulate-lanceolate, acute. Gynostemium $11 \mathrm{~mm}$ long, woolly pubescent at the base only.

Etymology. - Dedicated to Pedro Ortiz Valdivieso, an eminent Colombian orchidologist.

Ecology. - No records.

Distribution. - Collected in the Colombian departments Vaupes and probably Cundinamarca.
Notes. - This species appears to be related to P. guianensis (Schltr.) C. Schweinf. \& Correll, but its hypochile is obtriangular, with a basal, oblong, pubescent callus and two prominent lamellae running to the base of epichile. The hypochile of $P$. guianensis is round-obovate in outline. The basal section of the lip is ventrally pubescent either side of the axis and the margins lightly ciliate; the middle nerve ventrally is gently sulcate for most of its length, dorsally quite strongly sulcate for the full length; lateral lobes obtuse to rounded.

\section{Acknowledgments}

This article was prepared thanks to the grant from the Polish Ministry of Science and Higher Education (N N303 58 1939 and N N303 81 2440).

\section{References}

DRESSLER, R. L. (2003a). Field guide to the orchids of Costa Rica and Panama. Cornell University Press.

Dressler, R. L. (2003b). Phylogeny and classification of the orchid family. Dioscorides Press.

Hágsater, E., V. Dumont \& A. M. Pridgeon (1996). Orchids: status survey and conservation action plan. IUCN, Gland and Cambridge. 


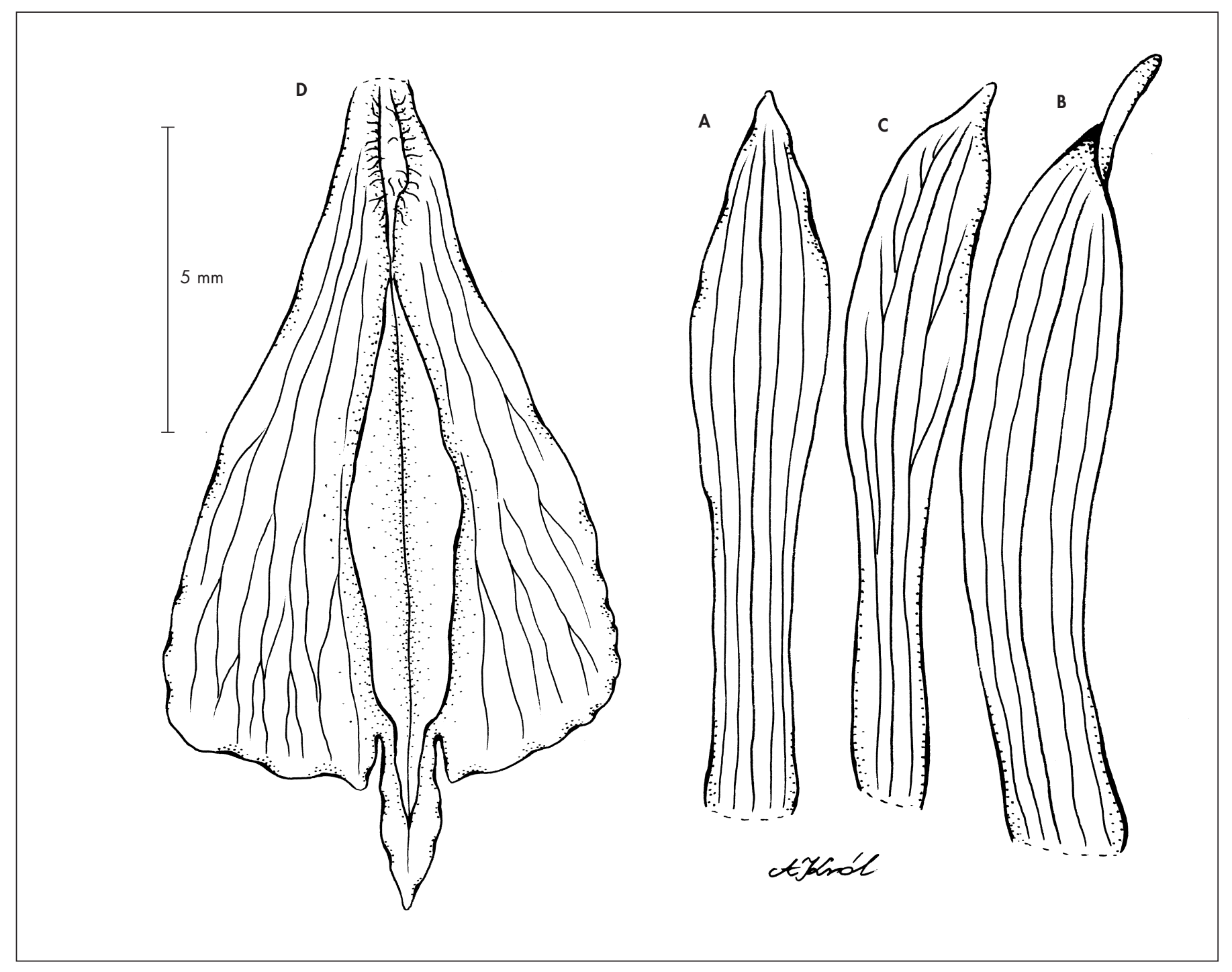

Fig. 5. - Palmorchis valdiviesoanus Szlach. \& Baranow: A. Dorsal sepal; B. Lateral sepal ; C. Petal; D. Lip. [Romero Castañeda 3843, COL] [Drawn by A. Król] 